\title{
On-Campus Pocket Parks for Enhancing Outdoor Learning Experience in Malaysian Universities
}

Sarah Abdulkareem Salih, Sumarni Ismail, Nor Atiah Ismail

To Link this Article: http://dx.doi.org/10.6007/IJARBSS/v11-i10/11453 DOI:10.6007/IJARBSS/v11-i10/11453

Received: 20 August 2021, Revised: 23 September 2021, Accepted: 05 October 2021

Published Online: 16 October 2021

In-Text Citation: (Salih et al., 2021)

To Cite this Article: Salih, S. A., Ismail, S., \& Ismail, N. A. (2021). On-Campus Pocket Parks for Enhancing Outdoor Learning Experience in Malaysian Universities. International Journal of Academic Research in Business and Social Sciences, 11(10), 831-846.

\section{Copyright: (c) 2021 The Author(s)}

Published by Human Resource Management Academic Research Society (www.hrmars.com)

This article is published under the Creative Commons Attribution (CC BY 4.0) license. Anyone may reproduce, distribute, translate and create derivative works of this article (for both commercial and non-commercial purposes), subject to full attribution to the original publication and authors. The full terms of this license may be seen at: http://creativecommons.org/licences/by/4.0/legalcode

\section{Vol. 11, No. 10, 2021, Pg. $831-846$}

Full Terms \& Conditions of access and use can be found at http://hrmars.com/index.php/pages/detail/publication-ethics 


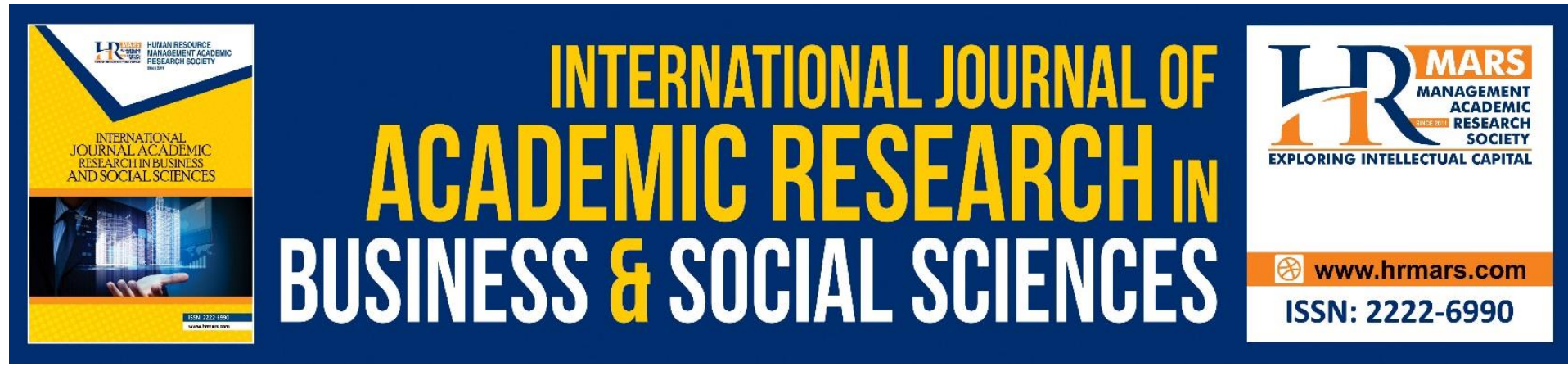

\title{
On-Campus Pocket Parks for Enhancing Outdoor Learning Experience in Malaysian Universities
}

\author{
Sarah Abdulkareem Salih ${ }^{1}$, Sumarni Ismail ${ }^{1}$, Nor Atiah Ismail ${ }^{2}$ \\ ${ }^{1}$ Department of Architecture, Faculty of Design and Architecture, Universiti Putra Malaysia, \\ Jalan UPM, 43400 Serdang, Selangor, Malaysia, ${ }^{2}$ Department of Landscape Architecture, \\ Faculty of Design and Architecture, Universiti Putra Malaysia, Jalan UPM, 43400 Serdang, \\ Selangor, Malaysia filiation \\ Email: sarah_alsaadi1990@yahoo.com, sumarni.upm@gmail.com, natiah@upm.edu.my
}

\begin{abstract}
Recently, small nearby outdoor spaces have become an important tool to improve academic outcomes by enhancing students' social-learning experience. However, nearby open spaces and pocket parks of Malaysian universities lack the absorption of informal and formal outdoor education that may affect the academic experience, especially in the outdoor spaces. Therefore, there is a need to enhance students' on-campus learning experience in Malaysian universities. This study aimed to investigate the visually preferred pocket parks criteria to promote students' learning experience on Malaysian campus grounds; this is in line with the Twelfth Malaysia Plan for 2021-2025. This study employed a visual-verbal preference survey (VVPS) conducted in three Malaysian universities, including Universiti Malaya (UM), Universiti Putra Malaysia (UPM), and Universiti Kebangsaan Malaysia (UKM), to assess the visual preferences of 415 students toward six pocket parks sceneries. Multiple regression analysis was used to predict the relationship between students' outdoor learning experience and preferred pocket parks criteria. The result showed that pocket parks that provide a strong shade, variety in softscape and activities, and bench hardscape contributed to enhancing students' outdoor learning. The result indicated that providing on-campus pocket parks with the preferred design criteria can enhance the learning experience. Thus, the current study contributed to integrating nearby pocket parks in outdoor learning to improve campus urban design and academic experience. The study's findings are of great importance for policymakers and academic administration, landscape and urban planners, and researchers in the field in creating an academically responsive campus.
\end{abstract}

Keywords: Pocket Parks, Small Nearby Open Spaces, Learning Experience, Visual-Verbal Preference Survey, Malaysian Universities.

\section{Introduction}

Learning happens when individuals interact with each other in a social-environmental context. Higher education has recently become an urgent need in societies, with competent researchers seeking to develop new learning approaches, including informal learning approaches (Rea, 2009). Barnett (2011) confirmed that university and higher education 
settings should respond to students' diverse cultural, social, and academic needs. Various learning settings must be integrated on-campus grounds to achieve the desired goals, including physical and virtual, formal and informal, outdoor, personal, and practice-based spaces (Rea, 2009; Keppell et al., 2011). These new settings must provide attractive physical learning environments equipped with proper design parameters to enhance new ways of academic teaching (Ibrahim et al., 2013; Kim and Lee, 2015), where traditional learning approaches and settings alone do not fit modern learning experience and needs.

Consequently, outdoor learning settings designed with the proper conditions, components, and criteria enhance the informal and formal participatory learning experience. Outdoor settings on-campus ground is a type of nearby public space that may include plazas, pathways, nearby pocket parks (NPPs), and natural landscapes (Dugdale, 2009; Keppell et al., 2011). Outdoor learning spaces are also sociable learning spaces that positively correlate with increased levels of students' engagement and formal and informal learning activities that contribute to the learning experience (Matthews et al., 2009; Rea, 2009; Keppell et al., 2011). These spaces allow the students to interact, discuss, participate, study, and cooperate with colleagues. Many universities worldwide have realized that new learning spaces, such as nearby open spaces, are required to promote student-centred teaching and collaborative activities (Keppell et al., 2011). On-campus pocket parks help engage in a range of formal or informal learning activities and interact with landscape elements, supporting the learning experience (Ibrahim and Fadzil, 2013). Outdoor learning pockets also enhance positive attitudes by promoting a sense of freedom to interact with colleagues and search for natural environment materials (Ali et al., 2014).

On the other hand, pocket parks refer to safe, low-cost, nearby small spaces (less than $4000 \mathrm{~m}^{2}$ ) that effectively promote various benefits and activities (Currie, 2016; Tabassum, 2018). Pocket parks provide nearby settings for community support, where they satisfy people's need for various events or where they convince each other (Currie, 2016; Lorenzo et al., 2016). Therefore, pocket parks can replace the high-cost large public parks and open spaces. Evidence also indicated that various learning activities constituted by multilateral groups of learners are required in nearby open spaces and pocket parks (Towers and Lynch, 2017; Hedges, 2018). Accordingly, responsible authorities in Europe and Asia focused on creating and maintaining small pocket parks rather than large parks, as Shahhoseini et al. (2015); Tabassum (2018) mentioned. Yet, these pockets must be designed with proper criteria to obtain the desired benefits (Hafner et al., 2018; Tabassum, 2018; Salih et al., 2019). The preferred criteria of pocket parks might vary from one region to another based on the sociodemographic characteristics and climate of the area (Salih and Ismail, 2017a, 2017b; Salih et al., 2020). Evidence from existing literature confirmed that the key criteria of the successful pocket parks included the landscape elements, including softscape elements (Nordh et al., 2011; Peschardt and Stigsdotter, 2014), hardscape elements (Abd El-Aziz, 2015; Salih et al., 2020), and environmental elements such as natural shade (Gibson and Canfield, 2016). Multilayered activities in NPPs also contributed to providing a unique experience for pockets users (Nordh and Østby, 2013; Abd El-Aziz, 2015; Salih and Ismail, 2018a, 2018b).

In Malaysia, higher education institutions made a recent move to transform the tertiary education landscape, a beacon for harmony by bridging racial differences. Under the Ministry of Higher Education, the Malaysian higher education sector is responsible for the operation of higher education institutions that consist of 20 public universities, 38 private universities, ten private university-colleges, 12 foreign branch campuses, 403 active private colleges, and 34 polytechnics. They have houses 1,253,501 students, of whom 153,328 were international 
students from more than 163 countries in 2018 (Ibrahim and Fadzil, 2013; Da Wan et al., 2015). Malaysian Higher education institutions were in a unique position to address social diversity and learning issues by creating an environment that allows for positive interactions among students from different ethnicities and backgrounds (Tahir et al., 2009; Ibrahim et al., 2013). In line with the Twelfth Malaysia Plan for 2021-2025, Malaysian authorities seek to develop the Malaysian higher education pathway through access to good quality education and learning experience in various settings on the campus ground (Economic Planning Unit, 2016). Initial studies from Malaysia confirmed that Malaysian universities must provide a proper natural nearby environment to enhance students' contribution, health, recreation, learning activities, and teaching outcomes (Akhir et al., 2018). However, underutilization of the outdoor learning spaces persists, especially in public universities, where outdoor learning spaces and extracurricular activities on the Malaysian campus ground remain neglected and unexplored (Ibrahim et al., 2013; Rasli et al., 2019). In addition, there is a lack of evidence on the impact of pocket parks on learning experiences on-campus ground (Rasli et al., 2019). Therefore, there is a need to promote the learning experience in nearby outdoor spaces oncampus grounds in Malaysian universities. The current paper investigated the visually preferred criteria of pocket parks for promoting students' outdoor learning experience in Malaysian universities.

\section{Methods}

\section{Study Design and Sampling}

In the current study, a visual-verbal preference survey (VVPS) was employed to investigate the visually preferred criteria of six pocket park sceneries and their relationship to students' outdoor learning experience in Malaysian universities. There are 20 public universities and 38 private universities in Malaysia that have about 700,000 students inrolment in different programs (Wan et al., 2015). Of which there are five research universities, including Universiti Malaya (UM), Universiti Kebangsaan Malaysia (UKM), Universiti Sains Malaysia (USM), Universiti Putra Malaysia (UPM), and Universiti Teknologi Malaysia (UTM). The students of the research universities in Malaysia have quality knowledge on developing research work (Sheriff and Abdullah, 2017). Therefore, the current study applied a stratified judgmental sampling technique to select a proper sample from the students of Malaysian universities (Lavrakas, 2008). The stratified judgment sample led to include respondents from the architecture school at three Malaysian public research universities, namely, UM, UPM, and UKM. According to Taherdoost (2016) and Sheriff and Abdullah (2017), the targeted sample should be relevant to the subject of the study; thus, architecture students of these universities were targeted as a study sample. The sample size of the current study was identified based on the Simplified Formula of Yamane (1973). A total of 450 questionnaire forms (150 in each university) was distributed and self-administered in the nearby open spaces of the selected universities during weekdays between April and July 2019. The current study included 415 analyzed questionnaires, where 35 questionnaire forms were uncompleted and dis-included in the analysis. On average, 20 questionnaires were answered by respondents in one day.

\section{Visual-verbal Preference Survey}

The current study utilized a VVPS using web-based imported sceneries based on the recommendation of Zheng et al. (2011), Kaboudarahangi et al. (2013), and Mertens et al. (2019). Evidence from landscaping surveys employed VVPS using web-based imported sceneries due to that they are highly controlled, helping to improve the reliability of results 
(Hafner et al., 2018; Mertens et al., 2019). The current study collected the imported sceneries from four electronic databases, including Pinterest Visual Search Tool, Shutterstock Stock Images, ArchDaily, and Google Images. The keywords of the systematic search included pocket parks, nearby open spaces, on-campus pocket parks, on-campus open spaces, AND tropical climate, hot, humid weather AND tropical region, subtropical region, or hot-humid region. This systematic search led to access to 584 sceneries for pocket parks. However, 504 photographs were excluded due to their resolution (less than 700 pixels in width), or the sceneries did not represent pocket parks from tropical or hot humid weather. The targeted sceneries must represent pocket parks from tropical regions or summer hot-humid weather to ensure that the selected sceneries represent pocket parks of climate conditions close to Malaysia climate. This systematic search led to include 80 sceneries presented to random volunteers from the Faculty of Design and Architecture, UPM, in March 2019. The volunteers in the early stage of the VVPS were 130 students, 88 Bachelor students, 25 master students, ten Doctoral students, and seven experts (lecturers). This stage led to include six most preferred sceneries, three from each group, for the questionnaire survey (see Table 1).

Table 1. Description of the Criteria of the Selected Pocket Parks

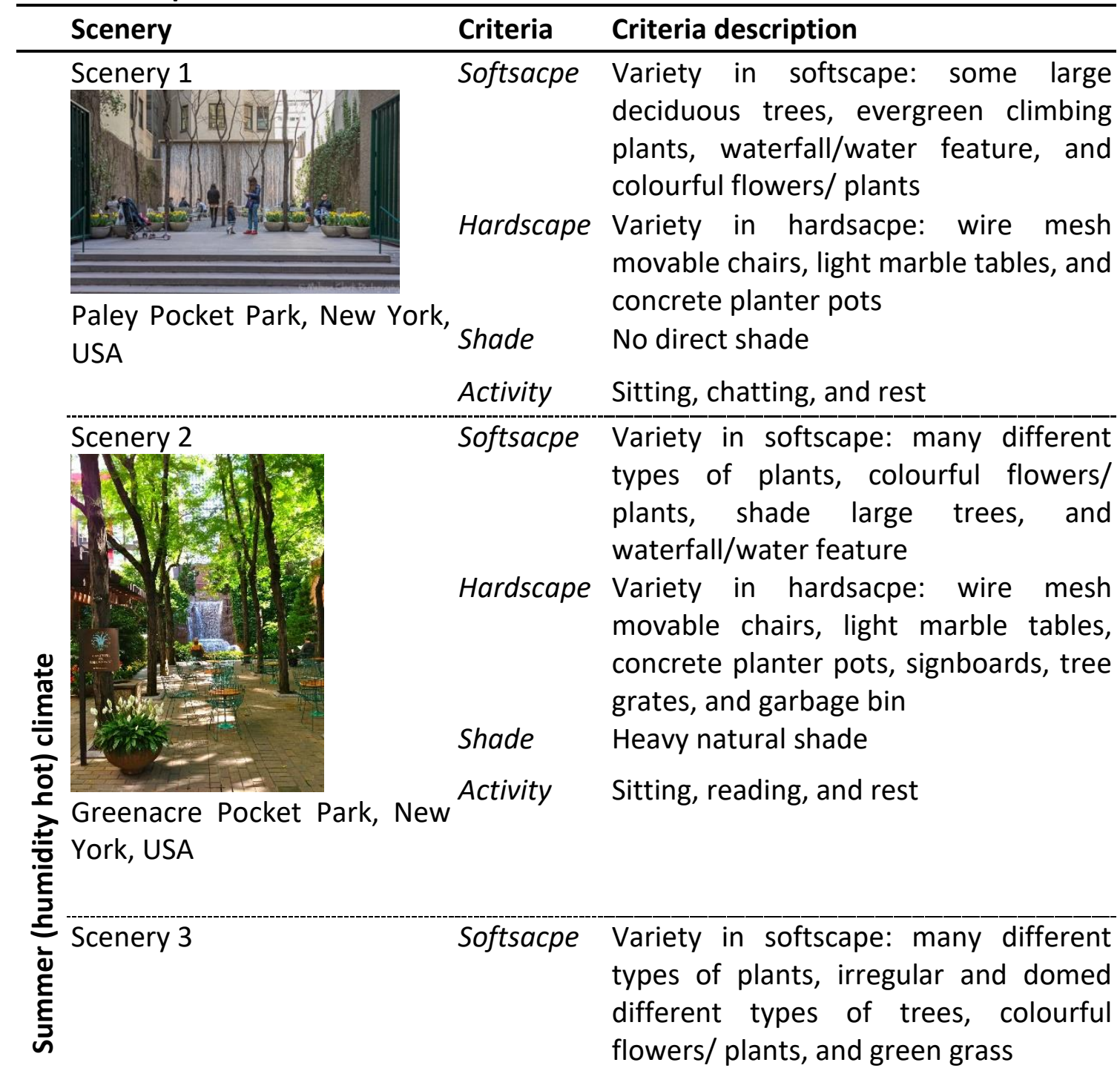




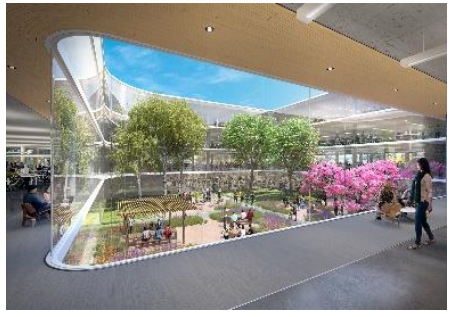

Hardscape Variety in hardsacpe: movable chairs, different types of bench/table, and movable tables

Shade Some natural shade from canopy trees

Activity Variety in activities: sitting, chatting, walking, studying, and watching

Courtyard Pocket, Central and Wolfe Campus, California, USA

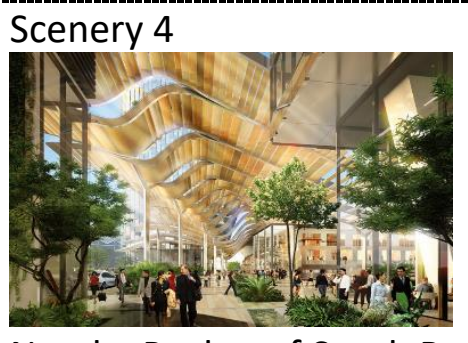

Nearby Pocket of South Beach Mixed-Use, Singapore
Softsacpe

Hardscape

Shade

Activity
Variety in softscape: many different types of plants, irregular and various forms of trees, shrubs/plants, and water features

\section{Comfortable, movable seats}

Strong artificial shade from wavy ribbons of steel and aluminium louvres supported by pillars

Variety in activities: walking, watching, phoning, and chatting

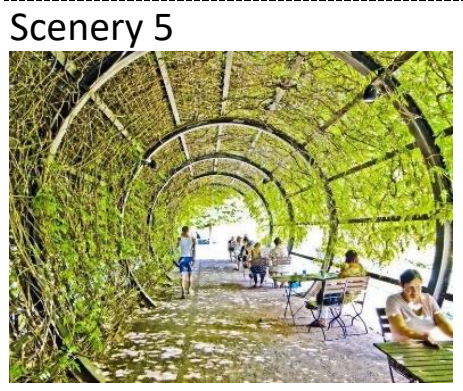

Softsacpe Climbing plants

Hardscape Many movable chairs and movable light tables

Shade Heavy natural shade from climbing plants (pergola shading device)

Activity Variety in activities: sitting, watching, chatting, walking, refreshment, and rest

Proposed Pocket Park in a Tropical Region

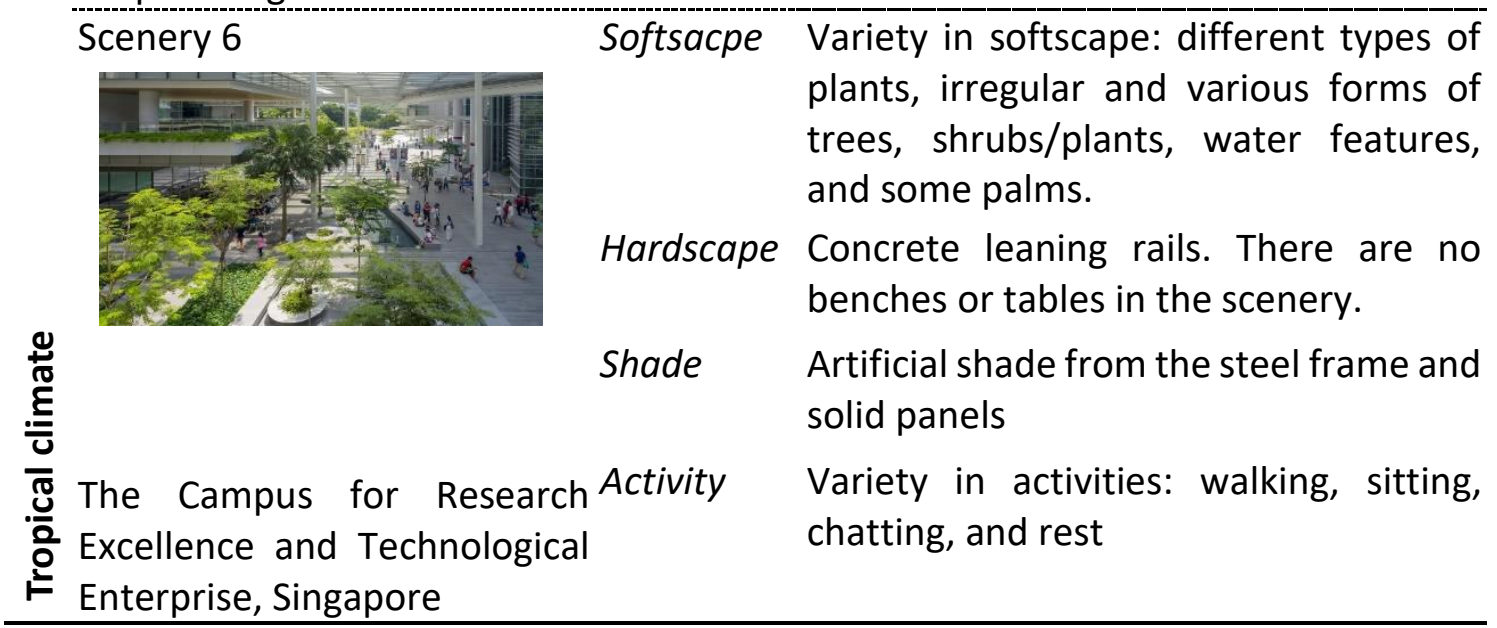

\section{Variables of the visual-verbal Preference Survey}

The VVPS consisted of three parts, including; a) demographic characteristics (participant variable), b) learning experience on-campus ground (dependent variable), and c) visual preference to pocket parks' criteria (independent variable). The demographic characteristics included age, gender (male and female); ethnicity (Malay, Chinese, Indian, and others); education level (Bachelor, Master, PhD, and others). The learning experience in nearby open 
spaces on-campus ground included three closed-ended questions regarding participants' outdoor group informal study, individual outdoor informal study, and outdoor group formal activities. The scale of this part was a three-point ratio scale: $1=$ never use them, $2=<30$ minutes daily, and $3=\geq 1$ hour daily. The last part included a closed-ended question regarding participants' visual preference to six imported sceneries of pocket parks, using a five-point Likert scale: $1=$ strongly not preferred, $2=$ not preferred, $3=$ undecided, $4=$ preferred, $5=$ strongly preferred. The content of the visual preference questionnaire developed after an intensive literature review for original studies published in indexed journals (Nordh et al., 2011; Zheng et al., 2011; De Vaus, 2013; Peschardt et al., 2014; Hecke et al., 2018; Mertens et al., 2019; Salih et al., 2020). Individual descriptions of each photograph were represented in Table 1.

\section{Reliability of the Visual-verbal Preference Survey}

A pilot test was conducted on 30 participants to check the VVPS scale clarity, time, and reliability. The pilot test showed that the VVPS scale is clear, and the participants took about 15 min to complete the questionnaire form. The Cronbach alpha score for internal consistency reliability was $0.76(>0.70)$ for the three items. Therefore, the pilot test showed that the VVPS scale was reliable and precise. The participants' involvement was voluntary, and they gave informed consent before applying the survey or any related procedure. The study protocol was approved by a committee of six experts from the Faculty of Design and Architecture at UPM in April 2019.

\section{Data Analysis}

First, descriptive statistics were used to analyze the primary data of demographic characteristics (participant variable), learning experience on-campus ground (dependent variable), and visual preference to pocket park (independent variable). Second, Pearson's correlation was utilized to analyze the bivariate correlation between the variables of the study. Third, multiple regression analyses were conducted to measure the multivariate relationships between the dependent variables (learning experience) and the participant variable (demographic characteristics), and the independent variable (preferred attributes of the pocket parks). The $p$-value of $<0.05$ was taken as significant. The collected data were analyzed using a statistical package for the social sciences (SPSS) version 23.

\section{Results}

\section{Demographic Characteristics}

A total of 415 participants were involved in the current study. Descriptive statistics of the sample demographic characteristics are presented in Table 2 . The mean age was $23.80 \pm 10.80$ years; $50.8 \%$ were females, and $48.9 \%$ were male; $49.4 \%$ were Bachelor students, $36.4 \%$ were Master's students, and $14.2 \%$ were PhD students of the total sample. Most of the participants were Malay (48.4\%), 30.1\% were Chinese, $14.1 \%$ were from other ethnicities, and $7.5 \%$ were Indian participants.

\section{Learning Experience in nearby Pockets on Malaysian Campus Ground}

The frequency statistics in Table 2 showed that the majority of the participants (63.4\%) had never used the nearby pocket parks (NPPs) on the Malaysian campus ground for outdoor group informal study. Only $3.9 \%$ of the participants used the nearby pockets daily for one hour or more for outdoor group informal study. About $47 \%$ have never used the NPPs for 
individual outdoor informal study; only $12.8 \%$ of them used these pockets for individual outdoor informal study for one hour or more daily. Besides, more than half of the participants (58.3\%) never used the nearby pockets for outdoor group formal activities. In comparison, only $9.4 \%$ of them used the on-campus pockets for outdoor group formal activities for one hour or more daily (see Table 2). These results indicated that most students do not use the nearby pocket park on Malaysian campus ground for daily learning activities.

Table 2. Frequency Statistics of Demographic Characteristics and Learning Experience

\begin{tabular}{lllllll}
\hline Variable & & N & $\%$ & $\begin{array}{l}\text { Range } \\
\text { s }\end{array}$ & Total & Missing \\
& & & & & \\
\hline Gender & Male & 203 & 48.9 & $1-2$ & 414 & 1 \\
Education & Female & 211 & 50.8 & & & \\
status & Bachelor & 205 & 49.4 & $1-3$ & 415 & - \\
Masters & 151 & 36.4 & & & \\
Ethnicity & PhD & 59 & 14.2 & & & \\
& Malay & 201 & 48.4 & $1-4$ & 415 & - \\
& Chinese & 125 & 30.1 & & & \\
outdoor group & Never use NPP & 263 & 63.4 & $1-3$ & 415 & - \\
informal study & $<30$ min daily & 136 & 32.8 & & & \\
& Indian & 31 & 7.5 & & & \\
Individual & Never use NPP & 193 & 46.5 & $1-3$ & 415 & - \\
outdoor & $<30$ min daily & 169 & 40.7 & & & \\
informal study & $\geq 1$ hour daily & 53 & 12.8 & & & \\
outdoor group & Never use NPP & 242 & 58.3 & $1-3$ & 415 & - \\
formal & $<30$ min daily & 134 & 32.3 & & & \\
activities & $\geq 1$ hour daily & 39 & 9.4 & & & \\
\hline
\end{tabular}

\section{Preferred Criteria of Pocket Park Sceneries}

Table 3 showed that the highest mean value of participants' visual preferences was registered for a pocket park 4 (Mean $=4.03, S D=0.90)$, following by visual preference for a pocket park 6 (Mean $=4.00, S D=0.97$ ). Both pocket parks showed a variety in softscape (plants and water feature), variety in activities, and a heavy artificial shade (see Table 1). Both pocket parks also showed few hardscapes (comfortable, movable seats or concrete leaning rails). In contrast, the lowest mean value was reported for a pocket park 1 (Mean= 3.49, SD=1.02). Although pocket park 1 showed variety in softscape and hardscape, it did not show any shading devices. In other words, the participants had higher visual preferences for pockets that contain a robust shading device. They also might have visual preferences for pockets show variety in softscape and activities. 
Table 3. Descriptive Statistics of Visually Preferred Criteria of Pocket Parks

\begin{tabular}{|c|c|c|c|c|}
\hline Variable & Mean \pm SD & Ranges & Total & Missing \\
\hline Visual preference to scenery 1 & $\begin{array}{l}3.49 \\
1.02\end{array}$ & $1^{*}-5^{* *}$ & 413 & 2 \\
\hline Visual preference to scenery 2 & $3.72 \pm 0.94$ & $1^{*}-5^{* *}$ & 414 & 1 \\
\hline Visual preference to scenery 3 & $\begin{array}{l}3.84 \\
0.94\end{array}$ & $1^{*}-5^{* *}$ & 415 & 0 \\
\hline Visual preference to scenery 4 & $\begin{array}{l}4.03 \\
0.90\end{array}$ & $1^{*}-5^{* *}$ & 413 & 2 \\
\hline Visual preference to scenery 5 & $3.74 \pm 0.95$ & $1^{*}-5^{* *}$ & 412 & 3 \\
\hline Visual preference to scenery 6 & $\begin{array}{l}4.00 \quad \pm \\
0.97\end{array}$ & $1^{*}-5^{* *}$ & 413 & 2 \\
\hline
\end{tabular}

\section{Preferred Pocket Park based on Demographics and Learning Activities}

Table 4 showed the bivariate Pearson's correlation to analyze the relationship between the learning activities in nearby open spaces in Malaysian universities, the visually preferred pocket parks, and demographic characteristics. Based on the results of Pearson's correlation, there was a significant negative association between outdoor group informal study and visual preferences to pocket parks four and six, and outdoor group formal activities and visual preferences to pocket parks four, five, and six ( $P<0.01$, see Table 4). Pearson's correlation also showed a negative association between the individual outdoor informal study on-campus ground and participants' visual preferences to pocket park 4 ( $P<0.05$, see Table 4). These results indicate that students who lacked outdoor learning activities on Malaysian campus grounds visually preferred pocket parks four, five, and six. However, there was a positive correlation between visual preferences to pocket park one and outdoor group informal study and outdoor group formal activities $(P<0.05)$. This result indicated that students who lacked outdoor group activities visually not preferred the pocket park in scenery one. Therefore, the significant results from the bivariate analysis were only included in the multiple regression analysis.

On the other hand, Pearson's correlation showed that participants' education status was significantly negatively associated with various learning activities on Malaysian campus ground ( $p<0.01$, see Table 4). Pearson's correlation showed a negative correlation between participants' gender and outdoor group informal study $(p<0.05)$ and individual outdoor informal study $(p<0.01)$. There was also a negative correlation between ethnicity and individual outdoor informal study $(p<0.05)$ and outdoor group formal activities $(p<0.01$, see Table 4). These results indicated that students from different demographics have different levels of learning activities on campus grounds. 
Table 4. Bivariate Analysis for the Relationships between Learning Activities, Visually Preferred Pocket Parks, and Demographics

\begin{tabular}{|c|c|c|c|c|c|c|c|}
\hline \multicolumn{2}{|c|}{ Variables } & \multirow{2}{*}{$\frac{1}{-}$} & \multirow[t]{2}{*}{2} & \multirow[t]{2}{*}{3} & \multirow[t]{2}{*}{4} & \multirow[t]{2}{*}{5} & \multirow[t]{2}{*}{6} \\
\hline 1 & $\begin{array}{l}\text { Outdoor group informal } \\
\text { study }\end{array}$ & & & & & & \\
\hline 2 & $\begin{array}{l}\text { Individual outdoor informal } \\
\text { study }\end{array}$ & - & - & & & & \\
\hline 3 & $\begin{array}{l}\text { Outdoor group formal } \\
\text { activities }\end{array}$ & - & - & - & & & \\
\hline \multirow[t]{2}{*}{4} & & & - & & & & \\
\hline & Gender & $.108^{*}$ & $.172^{*}$ & -.008 & - & & \\
\hline \multirow[t]{2}{*}{5} & Ethnicity & & & - & & & \\
\hline & & -.066 & $.104^{*}$ & ${ }_{*}^{.144^{*}}$ & - & - & \\
\hline \multirow[t]{2}{*}{6} & Education Status & - & - & - & & & \\
\hline & & $.238^{*}$ & $.181^{*}$ & $.216^{*}$ & - & - & - \\
\hline 8 & $\begin{array}{l}\text { Visual preference to scenery } \\
1\end{array}$ & $.101^{*}$ & .072 & $.117^{*}$ & -.007 & -.048 & -.026 \\
\hline 9 & $\begin{array}{l}\text { Visual preference to scenery } \\
2\end{array}$ & -.072 & .048 & .017 & .006 & $.102^{*}$ & -.075 \\
\hline $\begin{array}{l}1 \\
0\end{array}$ & $\begin{array}{l}\text { Visual preference to scenery } \\
3\end{array}$ & -.096 & -.045 & -.066 & -.010 & .048 & .032 \\
\hline 1 & Visual preference to scenery & - & & - & & & \\
\hline 1 & 4 & $.184^{*}$ & $.112^{*}$ & $.222^{*}$ & .032 & -.034 & .088 \\
\hline $\begin{array}{l}1 \\
2\end{array}$ & $\begin{array}{l}\text { Visual preference to scenery } \\
5\end{array}$ & -.073 & .007 & $.102^{*}$ & -.027 & -.002 & .080 \\
\hline 1 & Visual preference to scenery & - & & - & & & \\
\hline 3 & 6 &.$_{*}^{.142^{*}}$ & -.054 & ${ }_{*}^{.127^{*}}$ & -.089 & .031 & $.101^{*}$ \\
\hline
\end{tabular}

Note: The table reports Pearson's correlations.

${ }^{*} P<0.05$ (2-tailed).

${ }^{* *} P<0.01$ (2-tailed).

\section{Preferred Pocket Park that predicted Learning Experience}

Table 5 showed the multivariate correlation of multiple regression analyses among the overall learning experience on Malaysian campus ground, the visually preferred pocket parks, and demographic characteristics. The multiple regression analysis was used to investigate the visually preferred criteria of pocket parks sceneries for enhancing students' overall learning experience on Malaysian campus ground. The multiple regression analysis in Table 5 produced a significant model $(\mathrm{R} 2=0.076, \mathrm{~F}=8.333, \mathrm{P}<0.001)$ that showed a very statistically negative association between visual preference to pocket park four and overall learning experience on Malaysian campus ground $(\beta=-0.211, p<0.001)$. In addition, the multiple regression analysis showed a positive association between visual preference to pocket park one and overall learning experience $(\beta=0.158, p<0.01$, Table 5$)$. These results indicate that 
pocket park, which provides an artificial solid shade, various types of softscape and activities, and comfortable, movable seats, can enhance the on-campus learning experience in Malaysia. However, the pocket park that lacks a shading device or natural shade, no matter the other criteria, did not predict students' outdoor learning.

Table 5. Multiple Regression Analysis to predict Outdoor Learning Experience based on the Preferred Pocket Parks

\begin{tabular}{llll}
\hline Pocket Parks & $\mathbf{6}$ & $\mathbf{t}$ & Sig. \\
\hline (Constant) & & 12.246 & .000 \\
Scenery 1 & .158 & 3.249 & $\mathbf{. 0 0 1}^{* *}$ \\
Scenery 4 & -.211 & -3.957 & $\mathbf{. 0 0 0}^{* *}$ \\
& & & \\
Scenery 5 & -.004 & -.072 & .942 \\
Scenery 6 & -.078 & -1.527 & .127 \\
\hline
\end{tabular}

Dependent Variable: Overall (outdoor) learning experience. $R=0.267$, $\mathrm{R}^{2}=0.076, \mathrm{~F}=8.333$.

${ }^{* *} p<0.01$.

${ }^{* * *} p<0.001$.

\section{Discussion}

The current study found that providing pocket parks designed with an intensive artificial shade, comfortable, movable seat, and variety in softscape and activities contributes to enhancing the learning experience on Malaysian campus ground (see Figure 1). Whereby, students who lacked an outdoor learning experience tend to prefer pockets that provide a robust artificial shading device, variety in softscape and activity, and bench hardscape. However, pocket parks with no shading device or direct shade did not predict the outdoor learning experience of students in Malaysian universities. Therefore, intensive shade provided by an artificial shading device contributes to the critical criteria of successful oncampus pocket parks for enhancing outdoor experience, especially in tropical climates. This result could justify the reason for issue of parks utilization in hot, rainy climates. These findings are in line with the existing evidence from Hong Kong confirmed that shade has a significant effect on pocket park users, especially in hot summer weather (Lau et al., 2012). Strong correlations have been identified between the diversity of the softscape and the visual preferences of individuals, as reported by Polat and Akay (2015); Nordh et al (2009). Existing literature also found that variety in provided activities was a predictor of individuals' visual preferences in pocket parks (Mertens et al., 2019).

In terms of softscape, the findings revealed that providing different types and forms of trees and shrubs and water features in the NPPs can predict students' learning experience (see Figure 1). Results from Europe also showed that pocket parks must provide various natural elements such as flowers, plants, and water features to meet people's needs (Nordh and $\varnothing$ stby, 2013). Students from Malaysian universities, who lacked outdoor learning experience, also showed higher preferences to pocket parks that provide sitting, chatting, walking, studying, and watching activities. Findings from Egypt reported by Abd El-Aziz (2015) also found strong relationships between providing a seat and various activities (such as sitting, walking, biking, and watching) and users' preferences to NPPs. However, a study from Denmark by (Peschardt et al., 2012) reported that pocket parks are primarily used for socializing and restitution activity. This different result may be due to variations in pocket park 
size (pockets size may vary from few square meters up to $4000 \mathrm{~m} 2$ ). A large-scale pocket park promotes a wide range of activities than smaller pockets (Salih et al., 2020). In addition, users' activity could vary based on their socio-demographic backgrounds from one region to another.

Individually, the bivariate analysis of the current study asserted that pocket parks with a durable shading device, different types of softscape and activities, and some benches were preferred for students' outdoor group informal and formal study. Besides, a durable artificial shading device, variety in softscape and activities, and comfortable-movable benches in NPPs were predictors of individual outdoor informal study in Malaysian universities (see Figure 1). The findings concur with Ibrahim and Fadzil's (2013) results, in which the availability of various types of landscape elements and activities were usually essential for users of small parks on campus ground. Simlarly, Hecke et al (2018) confirmed that bench elements in NPPs contributed to enhance users' visual preferences. In addition, the bivariate analysis of the current study indicated that students from different education statuses have different levels of on-campus learning activities. Students from other gender showed different levels of outdoor group and individual informal study.

Furthermore, students from different ethnicities showed different levels of individual outdoor informal study and outdoor group formal activities in Malaysian universities. These findings contributed to the evidence from existing literature found that individuals' experience in nearby small parks could vary $n=$ based on their socio-demographic backgrounds (Zheng et al., 2011), such as age (Abd El-Aziz, 2015), gender (Salih and Ismail, 2018b), and education (Mertens et al., 2019). However, an experimental study conducted in the USA reported homogenous responses across demographic variables (Cohen et al., 2014). These different results may be due to other participants' activities that were included in that study.

On the other hand, the descriptive analysis of the current study showed that most of the students are not using the existing nearby pockets in the Malaysian universities for learning activities, including informal group learning, informal individual learning, and formal learning activities. This result is consistent with the finding reported by Shamsuddin et al. (2012), in which outdoor settings in Malaysian education institutes lack conducive sociallearning activities. However, Ibrahim and Fadzil (2013) confirmed that Malaysian higher education institutes must promote outdoor learning settings by enhancing the nearby open spaces. Based on Hecke et al (2018), young people and students should engage in daily outdoor activity to obtain various health, social, and learning benefits.

Therefore, the study's findings contributed to the pocket park's preferred design criteria for enhancing the learning experience on Malaysian campus grounds. These criteria included an artificial solid shade, variety in softscape and activity, and proper hardscape elements. The current study suggested that on-campus pocket parks with preferred design criteria respond better to the campus community by fulfilling the multiple learning benefits. Evidence from existing literature also confirmed that preferred pocket parks could enhance the individual outdoor experience (Peschardt et al., 2014; Salih et al., 2020). Therefore, the current findings are of great importance for policymakers and academic administration, landscape and urban planners, and researchers in creating an academically responsive campus. 


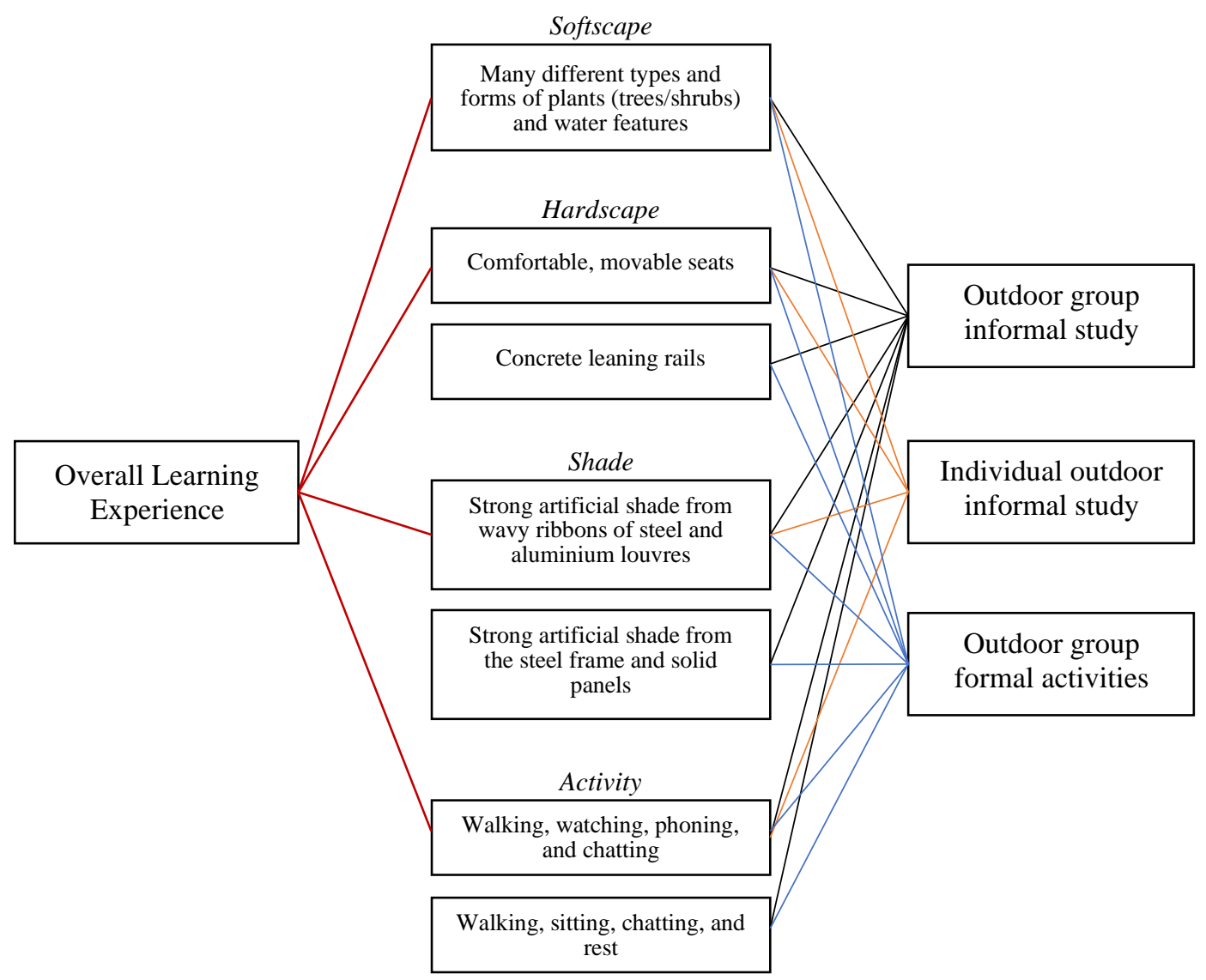

Figure 1. Pocket Park Criteria to enhance the Learning Experience in Malaysian Universities

The limitation of the current study included the judgment sampling selection, through selecting a sample from architecture schools at three public research universities in Malaysia. However, Taherdoost (2016) recommended choosing a specific group of individuals in sample selection to increase the external validity of the research. In addition, the current study only investigated four design criteria of web-based imported pocket parks. However, design criteria such as people's presence and pocket size can be included in landscape preference surveys (Mertens et al., 2019). The current study recommends including more designs criteria of NPPs in future research. Including more design criteria would help architects and landscape designers design the right pockets parks for the community.

\section{References}

Abd El-Aziz, N. A. (2017). Pocket Park Design in Informal Settlements in Cairo City, Egypt. Landscape Architecture and Regional Planning, 2(2), 51-60. http://www.sciencepublishinggroup.com/journal/paperinfo?journalid=241\&paperld $=10020954$

Akhir, N. M., Sakip, S. R., Abbas, M. Y., \& Othman, N. (2018). Landscape Spatial Character: Students' preferences on outdoor campus spaces, Asian Journal of Quality of Life, 13(13), 89-97. doi:10.21834/ajqol.v3i13.165

Ali, S. M., Rostam, K., \& Awang, A. H. (2014). School Landscape Environments in Assisting the Learning Process and in Appreciating the Natural Environment. Social and Behavioral Sciences, 202, 189-198. doi:10.1016/j.sbspro.2015.08.222 
Barnett, W. S. (2011). Effectiveness of Early Educational Intervention. Science, 333(6045), 975-978. doi:10.1126/science.1204528

Cohen, D. A., Marsh, T., Williamson, S., Han, B., Derose, K. P., Golinelli, D., \& McKenzie, T. L. (2014). The Potential for Pocket Parks to Increase Physical Activity. American Journal of Health Promotion, 28(3), 9-26. doi:10.4278/ajhp.130430-quan-213

Currie, M. A. (2016). A design framework for small parks in ultra-urban, metropolitan, suburban and small town settings. Urban Design, 22(1), 76-95. doi:10.1080/13574809.2016.1234334

Da Wan, C., Sirat, M., \& Razak, D. (2015). The Idea of a University: Rethinking the Malaysian Context. Humanities, 4(3), 266-282. doi:10.3390/h4030266

De Vaus, D. (2013). Surveys in Social Research (6th ed). Routledge.

Dugdale, S. (2009). Space Strategies for the New Learning Landscape. Educause Review, 44 (2), pp. 51-63. https://er.educause.edu/articles/2009/3/space-strategies-for-thenew-learning-landscape

Economic Planning Unit. (2016). The Eleventh Malaysia Plan, 2016-2020. Putrajaya: Prime Minister's Department, Malaysia. https://policy.asiapacificenergy.org/node/2508

Gibson, H., \& Canfield, J. (2016). Pocket parks as community building blocks: A focus on Stapleton, CO. Community Development, 47(5), 732-745. doi:10.1080/15575330.2016.1220965

Hafner, K., Zasada, I., Zanten, B., T., Ungaro, F., Koetse, M., \& Piorr, A. (2018). Assessing landscape preferences: a visual choice experiment in the agricultural region of Märkische Schweiz, Germany. Landscape Research. 43(6), 846-861. doi: org/10.1080/01426397.2017.1386289

Hecke, L. V., Ghekiere, A., Cauwenberg, J., Veitch, J., Bourdeaudhuij, I., Dyck, D., Clarys, P., Weghe, N., \& Deforche, B. (2018). Park characteristics preferred for adolescent park visitation and physical activity: A choice-based conjoint analysis using manipulated photographs. Landscape and Urban Planning, 178, 144-155. doi:10.1016/j.landurbplan.2018.05.017

Hedges, H. (2018). The "fullness of life": Learner interests and educational experiences. Learning, Culture and Social Interaction. doi:10.1016/j.Icsi.2018.11.005

Ibrahim, N., \& Fadzil, N. H. (2013). Informal Setting for Learning on Campus: Usage and preference. Social and Behavioral Sciences, 105, 344-351. doi:10.1016/j.sbspro.2013.11.036

Ibrahim, N., Fadzil, N., H. and Saruwono, M. (2013). Learning outside Classrooms on-Campus Ground: Malaysia. Asian Journal of Environment-Behaviour Studies, 4(13), 97-109. doi:10.21834/ajbes.v3i9.68

Kaboudarahangi, M., Tahir, O., Shariff, M., \& Maulan, S. (2013). Factors influencing preferences of garden iconographies. Social Science and Humanities, 21(4), 13951409. http://psasir.upm.edu.my/id/eprint/39801

Keppell, M., Souter, K., \& Riddle, M. (2012). Physical and Virtual Learning Spaces in Higher Education: Concepts for the Modern Learning Environment (1st ed). IGI Global.

Kim, Y. L., \& Lee, S. M. (2015). Effect of Satisfaction in Major at University on Academic Achievement among Physical Therapy Students. Journal of Physical Therapy Science, 27(2), 405-409. doi:10.1589/jpts.27.405

Lavrakas, P. J. (2008). Encyclopedia of Survey Research Methods (1st ed). SAGE Publications. 
Lau, S. S., Lin, P., \& Qin, H. (2012). A preliminary study on environmental performances of pocket parks in high-rise and high-density urban context in Hong Kong. International Journal of Low-Carbon Technologies, 7, 215-225. doi:10.1093/ijlct/cts033

Lorenzo, E., Corraliza, J.A., Collado, S., Sevillano, V., 2016. Preference, restorativeness and perceived environmental quality of small urban spaces. Bilingual Journal of Environmental Psychology, 7(2), 152-177. doi:/10.1080/21711976.2016.1149985

Mertens, L., Van Cauwenberg, J., Veitch, J., Deforche, B., \& Van Dyck, D. (2019). Differences in park characteristic preferences for visitation and physical activity among adolescents: A latent class analysis. PLOS ONE, 14(3), e0212920. doi:10.1371/journal.pone.0212920

Nordh, H., Alalouch, C., \& Hartig, T. (2011). Assessing restorative components of small urban parks using conjoint methodology. Urban Forestry \& Urban Greening, 10(2), 95-103. doi:10.1016/j.ufug.2010.12.003

Nordh, H., Hartig, T., Hagerhall, C. M., \& Fry, G. (2009). Components of small urban parks that predict the possibility for restoration. Urban Forestry \& Urban Greening, 8(4), 225235. doi:10.1016/j.ufug.2009.06.003

Nordh, H., \& Østby, K. (2013). Pocket parks for people: A study of park design and use. Urban Forestry and Urban Greening, 12, 12-17. doi:10.1016/j.ufug.2012.11.003

Peschardt, K. K \& Stigsdotter, U. K. (2014). Evidence for Designing Health Promoting Pocket Parks. ArchNet - IJAR, 8(3), 149-164. doi:10.26687/archnet-ijar.v8i3.341

Peschardt, K. K., Stigsdotter, U. K., \& Schipperrijn, J. (2014). Identifying Features of Pocket Parks that May Be Related to Health Promoting Use. Landscape Research Journal, 41(1), 79-94. doi:10.1080/01426397.2014.894006

Peschardt, K. K., Schipperijn, J., \& Stigsdotter, U. K. (2012). Use of Small Public Urban Green Spaces (SPUGS). Urban Forestry \& Urban Greening, 11(3), 235-244. doi:10.1016/j.ufug.2012.04.002

Polat, A. T., \& Akay, A. (2015). Relationships between the visual preferences of urban recreation area users and various landscape design elements. Urban Forestry \& Urban Greening, 14(3), 573-582. doi:10.1016/j.ufug.2015.05.009

Rasli, F. N., Kanniah, K. D., \& Ho, C. S. (2019). Analysis of Fragmented Green Spaces in Kuala Lumpur, Malaysia. Chemical Engineering Transactions, 72, 457-462. doi:org/10.3303/CET1972077

Rea, T. (2009). Informal learning outdoors. In S. Gibson \& J. Haynes (Eds.), Perspectives on Participation and Inclusion: Engaging Education (pp. 122-131). Continuum International.

Salih, S. A., \& Ismail, S. (2017a). Criteria for Public Open Space Enhancement to Achieve Social Interaction: a Review Paper. Materials Science and Engineering, 291, 012001. doi:10.1088/1757-899x/291/1/012001

Salih, S. A., \& Ismail, S. (2017b). Means to Achieve Social Interaction in Green Open Space in Baghdad, Iraq. Built Environment, Technology and Engineering, 2, 159-167. doi: psasir.upm.edu.my/id/eprint/62365

Salih, S. A., \& Ismail, S. (2018a). Green Open Spaces Criteria to Achieve Social Interaction of Karkh Community in the City Baghdad, Iraq. Materials Science and Engineering, 401, 012029. doi:10.1088/1757-899x/401/1/012029

Salih, S. A., \& Ismail, S. (2018b). Determining the Factors Affecting Social Interaction in the Parks of Baghdad City, Iraq. Archnet-IJAR, 12(3), 40-52. doi:10.26687/archnetijar.v12i3.1658 
Salih, S. A., Ismail, S., Ismail, N. A. (2019). Pocket Parks for Enhancing Residents' Social Interaction in the City of Baghdad, Iraq. International Journal of Engineering \& Technology, 8(1.9), 611-616. doi:10.14419/ijet.v8i1.9.30071

Salih, S. A., Ismail, S., \& Mseer, A. (2020). Pocket parks for promoting social interaction among residents of Baghdad City. Archnet-IJAR, 14(3), 393-408. doi:10.1108/arch-11-20190261

Shahhosseini, H., Kamal, M., Maulan, S. (2015). Visual preferences of small urban parks based on spatial configuration of place. International Journal of Architectural Engineering \& Urban Planning. 25(2), 84-93. http://ijaup.iust.ac.ir/article-1-247-en.html

Sheriff, N., M. \& Abdullah, N. (2017). Research Universities in Malaysia: What Beholds? Asian Journal of University Education, 13(2), 35-50. https://eric.ed.gov/?id=EJ1207763

Tabassum, S. (2018). Environmental Response of Small Urban Parks in Context of Dhaka City. Journal of Physics, 953(1), 1-19. doi:10.1088/1742-6596/953/1/012038

Taherdoost, H. (2016). Sampling Methods in Research Methodology; How to Choose a Sampling Technique for Research. International Journal of Academic Research in Management, 5(2), 18-27. doi:10.2139/ssrn.3205035

Tahir, M. M., Abdullah, N. A., Usman, I. M., Che, A. I., Mohd, N. F., \& Surat, M. (2009). Constructing place and space in the design of learning environments for PBL in Malaysian universities. Journal of Teaching and Learning in Higher Education, 1(1), 2634. https://ejournal.ukm.my/ajtlhe/article/view/10459

Towers, D., \& Lynch, J. (2017). What kind of outdoor educator do you want to become? Trying something different in outdoor studies in higher education. Journal of Hospitality, Leisure, Sport \& Tourism Education, 21, 117-121. doi:10.1016/j.jhlste.2017.09.002

Yamane, T. (1973). Statistics: An Introductory Analysis (3rd ed). Harper and Rao.

Zheng, B., Zhang, Y., \& Chen, J. (2011). Preference to home landscape: wildness or neatness? Landscape and Urban Planning, 99(1), 1-8. doi:10.1016/j.landurbplan.2010.08.006 